\title{
Influence of Helicobacter pylori, sex, and age on serum gastrin and pepsinogen concentrations in subjects without symptoms and patients with duodenal ulcers
}

Sandro Mossi, Beat Meyer-Wyss, Eberhard L Renner, Hans S Merki, Gerdien Gamboni, Christoph Beglinger

\begin{abstract}
The relation between Helicobacter pylori $(H$ pylori) infection and fasting gastrin and pepsinogen-I and -II concentrations was evaluated in 278 volunteers without symptoms and the results were compared with the values obtained in 35 patients with duodenal ulcers. $H$ pylori infection was determined with the ${ }^{13} \mathrm{C}$-urea breath test in subjects without symptoms and with endoscopy, biopsy (histology and culture), and quick urease test (CLO-test) in patients with duodenal ulcers. Gastrin and pepsinogen-I and -II concentrations were assayed with specific radioimmunoassay systems. The results clearly indicate that fasting gastrin and pepsinogen-I and -II concentrations were significantly higher in $H$ pylori positive compared with $H$ pylori negative subjects. Neither age nor sex affected basal gastrin and pepsinogen concentrations in $H$ pylori negative subjects. Fasting gastrin, pepsinogen-I and -II concentrations in serum samples were similar in $\boldsymbol{H}$ pylori positive persons with no symptoms and those with duodenal ulcers suggesting that similar mechanisms are involved in increasing plasma concentrations of these variables in both populations. Hypergastrinaemia and hyperpepsinogenaemia are therefore probably secondary to active $\boldsymbol{H}$ pylori infection.

(Gut 1993; 34: 752-756)
\end{abstract}

Colonisation of the gastric mucosa by Helicobacter pylori ( $H$ pylori) is associated with chronic gastritis and peptic ulcer disease, but the role of $H$ pylori in the pathogenesis of peptic ulcer disease is still unclear. ${ }^{1}$ Thus although eradication of $H$ pylori has been shown to dramatically reduce ulcer relapse rates, ${ }^{23}$ we still do not know how $H$ pylori causes ulcers. Besides $H$ pylori, aggressive factors (acid, pepsin) are necessary for peptic ulcer pathogenesis. Measurement of serum gastrin and pepsinogen concentrations is considered a diagnostic tool to indirectly assess these factors. ${ }^{4}$ Information on the interrelations between $H$ pylori, chronic gastritis, and circulating gastrin or pepsinogen concentrations seems, however, confusing ${ }^{15}$ and in particular, there is no consensus on how the mechanisms interact.

Recently, it has been suggested that in humans gastric acid and serum pepsinogen secretion rates increase with age as does the prevalence of $H$ pylori infection. ${ }^{16}$ Although $H$ pylori infection was associated with decreased acid secretion rates in the few subjects studied, serum gastrin concentrations surprisingly did not differ between $H$ pylori positive and $H$ pylori negative subjects. ${ }^{6}$

The aim of this study was therefore to further explore the potential relation between serum gastrin and pepsinogen-I and -II concentrations and $H$ pylori infection in a large number of $H$ pylori positive and $H$ pylori negative, subjects without symptoms and to compare the results with those in patients with duodenal ulcers. We also aimed to re-evaluate the effects of age and sex on these variables.

\section{Methods}

The study was approved by the human research and review committees of the participating centres and subjects gave written informed consent.

\section{SUBJECTS WITHOUT SYMPTOMS}

Caucasian subjects without symptoms and without a history of dyspepsia, peptic ulcer disease, or other upper gastrointestinal symptoms or abdominal surgery (with the exception of appendectomy) were carefully recruited by word of mouth among coworkers, relatives, and friends of the investigators, and fellow workers. Some elderly subjects were recruited from senior citizens' homes or choirs. No one had taken any antacids, bismuth preparations, or other drugs to treat dyspepsia within the past year and nobody was taking antibiotics during the three months before the study. The 278 volunteers thus recruited comprised 155 men aged 21 to 91 years (median 42 years) and 123 women aged 18 to 83 years (median 43 years).

After an overnight fast, a ${ }^{13} \mathrm{C}$-urea breath test (UBT) was performed according to published methods ${ }^{7}$ and a plasma sample was obtained for gastrin, pepsinogen-I, and pepsinogen-II determinations. The plasma was stored at $-20^{\circ} \mathrm{C}$ until analysis.

\section{PATIENTS WITH DUODENAL ULCERS}

Patients referred for upper gastrointestinal endoscopy because of suspected duodenal ulcers were invited to participate in the study. The patients gave written informed consent. Exclusion criteria included previous gastric surgery, known bleeding diathesis, oral anticoagulation, or recent (during the three months before the study) treatment with bismuth compounds, antisecretory agents $\left(\mathrm{H}_{2}\right.$ antagonists, omeprazole), or antibiotics. Thirty five patients with duodenal ulcer at endoscopy were finally 


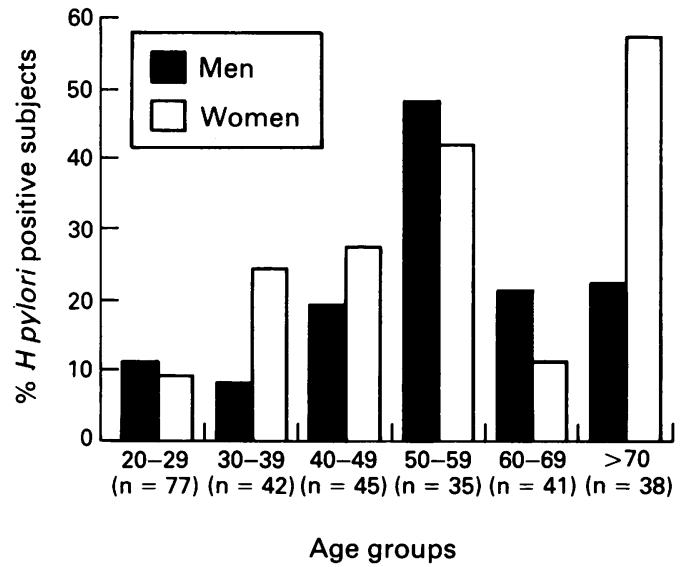

Figure 1: Prevalence of $\mathrm{H}$ pylori infection in a population without symptoms.

included (30 men aged 20 to 60 years, median 36 years; five women aged 26 to 50 years, median 36 years). During endoscopy, performed in the morning after an overnight fast, five biopsies were taken from the antrum for the detection of $H$ pylori: one for a quick urease test (CLO-test), two for culture with standard methods, ${ }^{8}$ and two for histology. The endoscopes were sterilised after each examination according to local standards; the biopsy forceps were sterilised by autoclaving. Based on these tests, all 35 subjects could be unequivocally classified as $H$ pylori positive. A plasma sample was taken for gastrin, pepsinogen-I, and pepsinogen-II determinations and stored at $-20^{\circ} \mathrm{C}$ until analysis.

\section{GASTRIN RADIOIMMUNOASSAY}

Radioimmunoassay of coded serum samples was performed as described recently. ${ }^{9}$

PEPSINOGEN-I AND -II RADIOIMMUNOASSAY

Radioimmunoassay for serum pepsinogen-I and -II of coded serum samples were performed with commercial kits (Pepsik-I and -II, SORIN Biomedica, Saluggia, Italy).

\section{STATISTICAL ANALYSIS}

For each variable examined, the difference between men and women was tested for significance by the non-parametric Mann-Whitney U test. Differences in each variable among $H$ pylori positive subjects (men or women) and $H$ pylori negative subjects (men or women) were tested by

Serum gastrin and serum pepsinogen concentrations (mean (SEM)) in $\mathrm{H}$ pylori negative and $\mathbf{H}$ pylori positive subjects without symptoms and patients with duodenal ulcers

\begin{tabular}{|c|c|c|c|c|c|}
\hline & \multicolumn{2}{|c|}{$\begin{array}{l}\mathrm{H} \text { pylori negative. No } \\
\text { symptoms }\end{array}$} & \multicolumn{2}{|c|}{$\begin{array}{l}\text { H pylori positive. No } \\
\text { symptoms }\end{array}$} & \multirow{2}{*}{$\begin{array}{l}\text { Patients with } \\
\text { duodenal } \\
\text { ulcers } \\
(n=35)\end{array}$} \\
\hline & $\begin{array}{l}M e n \\
(n=125)\end{array}$ & $\begin{array}{l}\text { Women } \\
(n=91)\end{array}$ & $\begin{array}{l}\text { Men } \\
(n=30)\end{array}$ & $\begin{array}{l}\text { Women } \\
(n=32)\end{array}$ & \\
\hline $\begin{array}{l}\text { Gastrin (pg/ml) } \\
\text { Pepsinogen-I }(\mathrm{ng} / \mathrm{ml}) \\
\text { Pepsinogen-II (ng/ml) } \\
\text { Ratio-I:-II }\end{array}$ & $\begin{array}{l}52(1) \\
62(2) \\
4 \cdot 3(0 \cdot 2) \\
15 \cdot 8(0 \cdot 5)\end{array}$ & $\begin{array}{l}58(2) \\
57(2) \\
4 \cdot 3(0 \cdot 2) \\
14 \cdot 9(0 \cdot 6)\end{array}$ & $\begin{array}{l}73(5)^{\star \star \star} \\
81(10)^{\star} \\
9 \cdot 3(1 \cdot 7)^{\star \star \star} \\
11 \cdot 4(1 \cdot 0)^{\star \star \star}\end{array}$ & $\begin{array}{l}74(5) \mathrm{Ht} \\
67(5) \dagger \\
7 \cdot 9(1 \cdot 0) \mathrm{tt} \\
11 \cdot 0(1 \cdot 0) \mathrm{tt}\end{array}$ & $\begin{array}{l}59(3)^{\star \star} \\
72(5)^{\star} \\
6 \cdot 7(0 \cdot 7)^{\star \star} \\
10 \cdot 4(0 \cdot 8)^{\star \star}\end{array}$ \\
\hline
\end{tabular}

${ }^{\star} \mathrm{p}<0.01 ;{ }^{\star \star} \mathrm{p}<0.001 ;{ }^{\star \star \star} \mathrm{p}<0.0001 v H$ pylori negative men by Mann-Whitney test.

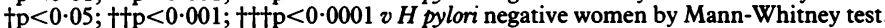

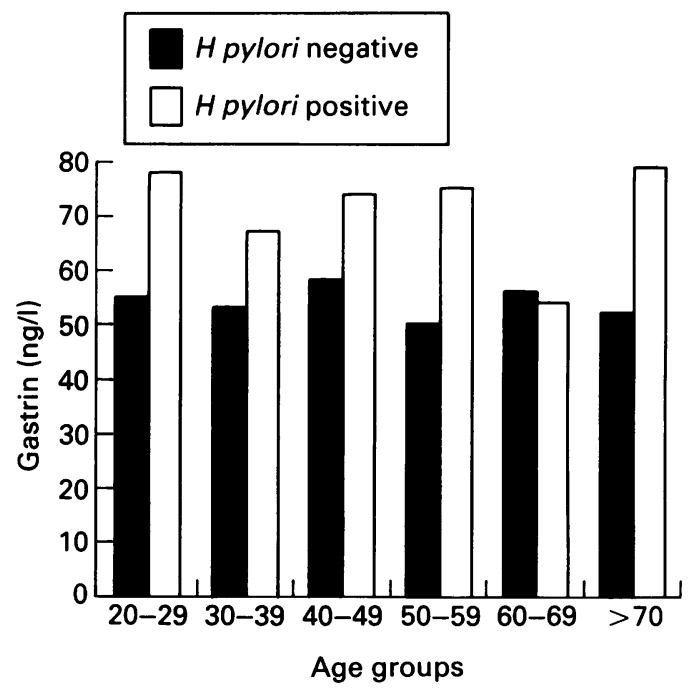

Figure 2: Mean age specific concentrations of fasting serum gastrin in $\mathrm{H}$ pylori positive and $\mathrm{H}$ pylori negative subjects without symptoms.

analysis of variance. If this step showed a significant difference for the variable examined, then pairs of subgroups were examined by the Newman-Keuls post hoc test. Differences in proportions in $H$ pylori positive and $H$ pylori negative subjects were evaluated by $\chi^{2}$ test. Correlation coefficients were calculated by Pearson's method. ${ }^{10} \mathrm{~A}$ p value $<0.05$ was considered significant.
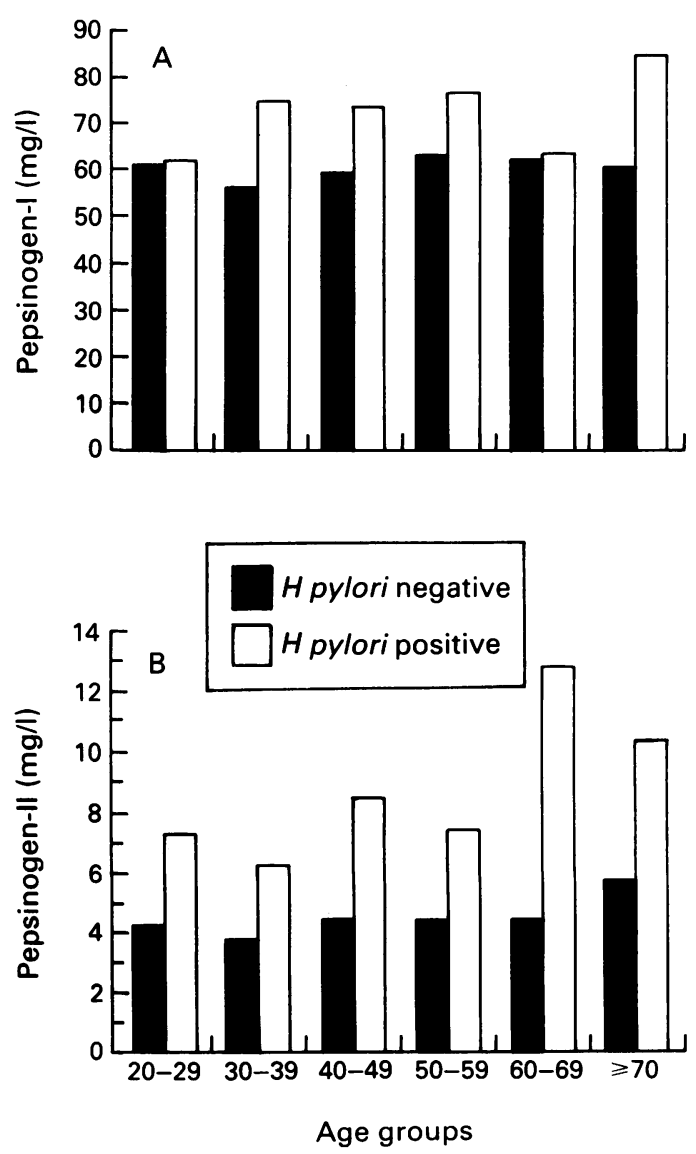

Figure 3: Mean age specific concentrations of fasting pepsinogen-I $(A)$ and pepsinogen-II $(B)$ in $\mathrm{H}$ pylori positive and $\mathrm{H}$ pylori negative subjects without symptoms. 
Results

\section{SUBJECTS WITHOUT SYMPTOMS}

$H$ pylori

$H$ pylori infection was present in 62 of 278 subjects - that is, in $22 \%$ of the population studied (Fig 1). The frequency of $H$ pylori infection in men and women was similar and increased with age as previously reported..$^{71-13}$

\section{Gastrin}

Basal serum gastrin concentrations were significantly higher in $H$ pylori positive than in $H$ pylori negative subjects $(\mathrm{p}<0.001)$. Age and sex did not significantly affect basal gastrin concentrations (Table, Fig 2), irrespective of $H$ pylori state.

\section{Pepsinogen concentrations}

Basal serum pepsinogen-I and -II concentrations were significantly higher in $H$ pylori positive than in $H$ pylori negative subjects (Table, Fig 3). There was a significant decrease in the ratio of pepsinogen-I to pepsinogen-II in $H$ pylori positive compared with $H$ pylori negative subjects $(\mathrm{p}<0.001)$, because in $H$ pylori positive subjects the increase in pepsinogen-II was more pronounced than the increase in pepsinogen-I. As with serum gastrin, neither age nor sex influenced serum pepsinogen concentrations.

\section{PATIENTS WITH DUODENAL ULCERS}

\section{$H$ pylori}

All 35 patients with duodenal ulcers were clearly identified as $H$ pylori positive (35 positive by culture, 35 positive by histology, 34 positive in the CLO-test).

\section{Gastrin}

As there were only five women with duodenal ulcer disease and as there were no differences apparent, the results shown in the Table are pooled for male and female patients. Basal serum gastrin concentrations were similar in patients with duodenal ulcers compared with $H$ pylori positive subjects without symptoms, but were significantly $(\mathrm{p}<0.001)$ higher than in $H$ pylor negative subjects without symptoms (Table). There was no effect of age on basal serum gastrin concentrations (data not shown).

\section{Pepsinogen concentrations}

Pepsinogen-I and pepsinogen-II concentrations in patients with duodenal ulcers were again similar to the values found in $H$ pylori positive, subjects without symptoms, but significantly higher than those in $H$ pylori negative subjects. Again, no age dependence was detectable (data not shown).

\section{Discussion}

The effect of age and sex on basal serum gastrin and pepsinogen secretion in healthy people as well as in patients with duodenal ulcers has been investigated previously by different groups. ${ }^{6}{ }^{13-19}$ Most of them did not control for a possible confounding effect of $H$ pylori infection. Moreover, in a recent study it was suggested that aging is associated with increasing gastrin and pepsinogen secretion in humans, particularly in men. ${ }^{6}$ Although infection with $H$ pylori was associated with lower acid secretion rates, no differences in basal gastrin concentrations were found between $H$ pylori positive and $H$ pylori negative subjects. Only 11 subjects with $H$ pylori infection were examined in the study, however. Here we have examined a large group of subjects without symptoms covering a broad age range and in whom the $H$ pylori state was known. Our findings can be summarised as: (1) basal gastrin and pepsinogen-I and -II concentrations were significantly influenced by $H$ pylori infection, being higher in $H$ pylori positive compared with $H$ pylori negative subjects; (2) in a large group of $H$ pylori negative subjects, neither age nor sex affected basal serum gastrin or pepsinogen concentrations.

In the present study, 62 of 278 Swiss subjects with no symptoms were $H$ pylori positive (22\%). This figure is comparable with data from other industrialised countries such as Great Britain, the United States, Japan, Australia, and New Zealand with an apparent overall prevalence of $15-25 \% .{ }^{20}$ Similarly, age was associated with an increase in $H$ pylori prevalence, but the peak of $H$ pylori positive subjects was found in the group aged between 50 and 60 years, whereas the rate tended to be lower in older subjects. This phenomenon as been noted previously by other groups ${ }^{20}$ and could be associated with progression of the chronic $H$ pylori gastritis to atrophic gastritis in elderly people, because severe gastric atrophy seems to make the stomach inhospitable to $H$ pylori. ${ }^{621} 22$ Alternatively, as teeth and gums have been proposed to act as a reservoir of $H$ pylori infection, ${ }^{23}$ people becoming more edentulous with increasing age may lose their $H$ pylori reservoir.

The present study has also confirmed that $H$ pylori affects circulating gastrin concentrations. ${ }^{24-27}$ Gastrin is a gut hormone produced by $\mathrm{G}$ cells located in the gastric antrum. ${ }^{28}$ The factors that regulate gastrin secretion are complex. Here we add to the complex as we have clearly shown that basal gastrin concentrations are neither affected by age nor by sex, but are influenced by $H$ pylori. As basal gastrin levels can be returned to normal with eradication of $H$ pylori, ${ }^{29-31}$ the data indicate that the increase in gastrin is induced by the infection. These findings have physiological and clinical implications. Firstly, $H$ pylori infection apparently interferes with the physiological mechanisms regulating gastrin release. Future studies evaluating mechanisms of gastrin release have to take into account the $H$ pylori state. Secondly, high gastrin concentrations may induce increased parietal cell mass and acid secretion, which in turn could contribute to the pathogenesis of duodenal ulceration. It has, however, not been shown up to now that eradication of $H$ pylori modifies parietal cell mass or acid secretion rates.

Recent work has focused on the gastrin acid 
secretion feedback loop and identified a number of potential pathogenetic pathways. ${ }^{32}$ The finding of enhanced fasting gastrin concentrations in $H$ pylori positive subjects and in duodenal ulcer disease cannot easily be explained. Firstly, $H$ pylori could increase gastrin release by production of ammonia through its enzyme urease. This would raise the $\mathrm{pH}$ within the antrum mucus layer, which in turn would prevent inhibition of gastrin release through a feedback mediated mechanism by low intragastric acidity. Secondly, gastrin concentrations could be increased through local inflammation as gastrin concentrations are also increased in patients with non- $H$ pylori induced gastritis. ${ }^{33}$ Beardshall and coworkers have shown that suppression of $H$ pylori with tripotassium dicitratobismuthate and metronidazole decreased the response of gastrin to gastrin releasing peptide stimulation. ${ }^{34}$ These findings support the hypothesis that $H$ pylori colonisation is directly involved in the hypergastrinaemia. Bismuth has, however, effects on the gastric mucosa apart from that on $H$ pylori. It is therefore possible that the changes found in the study of Beardshall et al are not related to suppression of $H$ pylori although this remains the most likely explanation. ${ }^{34}$ Further studies are still necessary to determine the mechanism by which $H$ pylori increases fasting plasma gastrin concentrations in $H$ pylori positive subjects and in patients with duodenal ulcer disease.

In the present study we also analysed the relation between active $H$ pylori infection and serum pepsinogen-I and pepsinogen-II concentrations. Both pepsinogens are present in the chief cells of the oxyntic glands of the gastric corpus mucosa, but only pepsinogen-II is present in the gastric antrum. We found that the serum concentrations of both pepsinogens were increased in persons without symptoms but with active $H$ pylori infection compared with those without $H$ pylori. Interestingly, the effect was more pronounced with pepsinogen-II, indicating that diffuse antral gastritis leads either to increased pepsinogen-II secretion or to increased leakage of pepsinogen-II into the circulation. Although the mechanism by which $H$ pylori infection produces hyperpepsinogenaemia remains unknown, it has been shown before that patients with gastritis have increased serum pepsinogen concentrations. ${ }^{356}$ In fact, measurement of pepsinogen concentrations had been proposed as a method for screening of gastritis. ${ }^{21}$ We have shown that the serum pepsinogen-I:-II ratio is significantly lower in $H$ pylori positive subjects than in uninfected persons. Again, neither age nor sex affected pepsinogen-I or pepsinogen-II concentrations.

The distribution and severity of chronic gastritis induced by $H$ pylori in patients with duodenal ulcer disease seems to be different from those in $H$ pylori positive subjects without symptoms. ${ }^{137-39}$ It might be anticipated, therefore, that the pattern of gastrin and pepsinogen would differ in $H$ pylori positive subjects without symptoms and in patients with duodenal ulcers. We have shown, however, that basal gastrin pepsinogen-I and -II concentrations are similar in these groups, suggesting that similar mecha- nisms are involved in increasing plasma concentrations of gastrin and pepsinogen in both populations. Similar results have recently been published for basal gastrin concentrations in a small group of subjects matched for sex and age. ${ }^{40}$

In summary, $H$ pylori infection is associated with increases in basal gastrin and pepsinogen-I, and pepsinogen-II concentrations. Basal gastrin and pepsinogen-I, and pepsinogen-II concentrations were not influenced by sex or age and were similar in patients with duodenal ulcers and in $H$ pylori infected volunteers without symptoms, suggesting that hypergastrinaemia and hyperpepsinogaenemia are secondary to active $H$ pylori infection.

We thank Carita Frei for editorial assistance and for typing the We thank Carita Frei for editorial assistance and for typing the manuscript. The study was supported by a grant
National Science Foundation (grant No 32-31336-91)

1 Moss S, Calam J. Helicobacter pylori and peptic ulcers: the present position. Gut 1992; 33: 289-92.

2 Rauws EAJ, Tytgat GNJ. Cure of duodenal ulcer associated with eradication of Helicobacter pylori. Lancet 1990: 1233-5.

3 Axon AR. Duodenal ulcer: the villain unmasked? Eradicating Helicobacter pylori will cure most patients. BMF 1991; 302 : 919-21.

4 Langman MJS, Kovacs TOG, Soll AH, Bianchi Porro G, Lazzaroni M, Gustavsson S. Peptid ulcer disease. In: Gustavsson S, Kumar D, Graham DY, eds. The stonach. Edinburgh: Churchill Livingstone, 1992: 219-45.

5 McKinlay AW, Upadhyay R, Gemmell CG, Russell RI Helicobacter pylori: bridging the credibility cap. Gut 1990 31: $940-5$

6 Goldschmiedt M, Barnett CC, Schwarz BE, Karnes WE Redfern JS, Feldman M. Effect of age on gastric acid secretion and serum gastrin concentrations in healthy men and women. Gastroenterology 1991; 101: 977-90.

7 Meyer B, Werth B, Beglinger C, et al. Helicobacter pylor infection in healthy people: a dynamic process? Gut 1991; 32: 347-50.

8 Dill S, Payne-James JJ, Misiewicz JJ, et al. Evaluation of ${ }^{13} \mathrm{C}$ urea breath test in the detection of Helicobacter pylori and in monitoring the effect of tripotassium dicitratobismuthate in non-ulcer dyspepsia. Gut 1990) 31: 1237-41

9 Beglinger C, Hildebrand $P$, Meier R, et al. A physiological role for cholecystokinin as a regulator of gastrin secretion. for cholecystokinin as a regulator

10 Sachs L. Angewandte Statistik. Anwendung statistischer Methoden. 6th ed. Berlin: Springer, 1984

11 Peterson WL. Helicobacter pylori and peptic ulcer disease. NEngl F Med 1991; 324: 1043-8.

12 Graham DY, Malaty HM, Evans DG, Evans DJ, Klein PD Adam E. Epidemiology of Helicobacter pylori in an asymptomatic population in the United States. Gastroenterology 1991 100: 1495-501.

13 Asaka M, Kimura T, Kudo M, et al. Relationship of Helicobacter pylori to serum pepsinogens in an asymptomatic Japanese population. Gastroenterology 1992; 201: 760-6.

14 Cleator IGM, Stoller JL, Nunn PN, Holubitsky IB, Johnstone FRC, Harrison RC. Discriminant analysis of data in ulcer FRC, Harrison RC. Discriminant analysis of data in

15 Fordtran JS, Walsh JH. Gastric acid secretion rate and buffer content of the stomach after eating. Results in normal content of the stomach after eating. Results in normal subjects and in pati

16 Hobsley M, Faber RG, Whitfield PF, Parkin JV. Hypersecretion and length of history in duodenal ulceration. Lance 1975; ii: $101-4$.

17 Kekki M, Samloff IM, Ihamaki T, Varis K, Siurala M. Ageand sex-related behaviour of gastric acid secretion at the population level. Scand $\mathcal{F}$ Gastroenterol 1982; 17: 737-43.

18 Feldman M, Richardson CT, Walsh JH. Sex-related differences in gastrin release and parietal cell sensitivity to gastrin in healthy human beings. $\mathcal{F}$ Clin Invest 1983; 71: 715-20.

19 Blair III AJ, Feldman M, Barnett C, Walsh JH, Richardson CT. Detailed comparison of basal and food-stimulated CT. Detailed comparison of basal and food-stimulated gastric acid secretion rates and serum gastrin concentrations 1987; 79: 582-7.

20 Dwyer B, Kaldor J, Tee W, Raios $K$. The prevalence of Campylobacter pylori in human populations. In: Rathbone BJ, Heatley RV, eds. Campylobacter pylori and gastroduodenal disease. Oxford: Blackwell Scientific Publications, 1990: 190-6.

21 Samloff IM, Varis K, Ihamaki T, Siurala M, Rotter JI. Relationships among serum pepsinogen I, serum pepsinogen II, and gastric mucosal histology. A study in relatives of patients with pernicious anemia. Gastroenterology 1982; 83: 204-9.

22 Kaneko H, Nakada K, Mitsuma T, et al. Helicobacter pylori infection induces a decrease in immunoreactivesomatostatin concentrations of human stomach. Dig Dis Sci 1992; 37: 409-16. 
23 Khandaker MAK, Scott A, Eastwood MA, Palmer KR. Do teeth predispose to duodenal ulcer relapse? Gut 1991; 32

24 Levi S, Beardshall K, Haddad G, Playford R, Ghosh P, Calam J. Campylobacter pylori and duodenal ulcers: the gastrin link. Lancet 1989; 1: 1167-9. 25 Levi S, Dollery CT, Bloom SR, et al. Campylobacter pylori,
duodenal ulcer disease, and gastrin. Hypergastrinaemia due to bacterial colonisation responds to antibiotics. $B M F 1989$; 299: 1093-5.

26 Smith JTL, Pounder RE, Nwokolo CU, et al. Inappropriate hypergastrinaemia in asymptomatic healthy subjects infected with Helicobacter pylori. Gut 1990; 31: 522-5.

27 Graham DY, Opekun A, Lew GM, Klein PD, Walsh JH. Helicobacter pylori-associated exaggerated gastrin release in Helicobacter pylori-associated exaggerated gastrin release in
duodenal ulcer patients. The effect of bombesin infusion and urea ingestion. Gastroenterology 1991; 100: 1571-5.

28 Daugherty DF, Lucey MR, Yamada T. Gastric secretion. In: Yamada T, Alpers DH, Owyang C, Powell DW, Silverstein FE, eds. Textbook of gastroenterology. Vol 1. Philadelphia: JB Lippincott Co, 1991: 233-64.

29 Levi S, Beardshall K, Swift I, et al. Antral Helicobacter pylori, hypergastrinaemia, and duodenal ulcers: effect of eradicating the organism. BMF 1989; 299: 1504-5.

30 McColl KE, Fullarton GM, El Nujumi AM, et al. Lowered gastrin and gastric acidity after eradication of Campylobacter gastrin and gastric acidity after eradication of $C a m$.

31 Graham DY, Opekun A, Lew GM, Evans DJ, Klein PD, Evans DG. Ablation of exaggerated meal stimulated gastrin release in duodenal ulcer patients after clearance of Helicobacter (Campylobacter) pylori infection. Am $\mathfrak{F}$ Helicobacter (Campylobacter)
Gastroenterol 1990; 85: 394-8.
32 Blaser MJ. Hypothesis on the pathogenesis and natural history of Helicobacter pylori-induced inflammation. Gastroenterology 1992; $102: 720$

33 Wyatt JI, Rathbone BJ, Green DM, Primrose J. Raised fasting serum gastrin in chronic gastritis is independent of Campylobacter pylori status and duodenal ulceration. Gut 1989; 30: A1483.

34 Beardshall K, Moss S, Gill J, Levi S, Ghosh P, Playford RJ, Calam J. Suppression of Helicobacter pylori reduces gastrin releasing peptide stimulated gastrin release in duodenal ulcer patients. Gut 1992; 33: 601-3.

35 Samloff IM. Pepsinogens I and II: purification from gastric mucosa and radioimmunoassays in serum. Gastroenterology 1981; 82: 26-33.

36 Sipponen P, Samloff IM, Saukkonen M, Varis K. Serum pepsinogens I and II and gastric mucosal histology after pepsinogens I and II and gastric mucosal

37 Tarpila S, Kekki M, Samloff IM, Sipponen P, Siurala M Morphology and dynamics of the gastric mucosa in duodenal ulcer patients and their first-degree relatives. Hepatogastroenterology 1983; 30: 198-201

38 Siurala M, Sipponen P, Kekki M. Chronic gastritis: dynamic and clinical aspects. Scand $\mathcal{F}$ Gastroenterol 1985; 20 (suppl 109): 69-76.

39 Villako K, Kekki M, Tamm A, Savisaari E. Development and progression of chronic gastritis in the antrum and body Clin Res 1986; 18: 121-3.

40 Chittajallu RS, Ardill JES, McColl KEL. The degree of hypergastrinaemia induced by Helicobacter pylori is the same in duodenal ulcer patients and asymptomatic same in duodenal ulcer patients and asympto
volunteers. Eur f Gastroenterol Hepatol 1992; 4: 49-53. 